\title{
reviscafuences
}

ISSN: 1575-7072 | e-ISSN: 2172-7775

Páginas: $39-53$

Recibido: 2021-05-26

Revisado: 2021-08-10

Aceptado: 2021-12-01

Preprint: 2022-01-01

Publicación Final: 2022-01-30

www.revistascientificas.us.es/index.php/fuentes/index

DOI: https://doi.org/10.12795/revistafuentes.2022.16822

\section{The Educational Use of the Smartphone by University Students of Social Education and Social Work}

\author{
iD Fernando López-Noguero \\ Universidad Pablo de Olavide (España) \\ iD José Alberto Gallardo-López \\ Universidad Pablo de Olavide (España)
}

\begin{abstract}
A smartphone is a mobile device increasingly present in the academic activities that take place in universities, becoming a technological tool with great educational potential. The goal of this research is to analyze how students use their smartphones in university contexts, and how they evaluate the use of these mobile devices as educational tools. The research methodology used responds to an ex post facto, quantitative, transversal, correlational and descriptive design, with a sample of 252 university students of Social Education and Social Work of the Pablo de Olavide University (Seville, Spain). As a method for collecting data the questionnaire "Smartphone and University Questionnaire. Student Perspective. SUQS"has been used. The research work provides outstanding conclusions for the field of study addressed, among the main results obtained, it is emphasized that the university students show a clear positive evaluation of the use of the smartphone as an educational tool in Higher Education, with the youngest students being those who use the smartphone the most at the university level. Also, numerous advantages stand out, such as the rapid search for information, access to content without spatial or temporal limitations, as well as its usefulness for academic management and organization and communication with other students, promoting the development of their learning. On the other hand, there are some negative aspects of the use of Smartphones in university contexts, such as dependency and stress that can lead to the misuse of this technology, or the negative impact that it can have on written communication.
\end{abstract}

\section{Keywords}

smartphones, mobile learning, higher education, university students, educational technology

\section{Introducción}

Today's society is radically marked by the gradual development of the so-called "Information and Communication Technologies" (ICTs) that define both, personal relations and access to information, interaction, and debate of ideas or diffusion of information. In recent decades, there have been practiced more advances in the field of information and communications than in any other time of human history, in a "digital tsunami" that is changing a multitude of social realities.

Thus, the human being has to face the consequences of the development of both mass media and ICTs. Through those both, every one of us has access to an infinite amount of data and information, enabling us to be aware of the most remarkable developments in all parts of the world and being, not only consumers but also creators and producers of information. This phenomenon has led to the development of a society of a planetary nature, a "global village" in which we are constantly developing and influencing ourselves (LópezNoguero \& Pérez Serrano, 2012).

The integration of technologies in people's lives, as is the case with Smartphones, modifies the nature of knowledge and discourse and, therefore, the nature of the teaching-learning processes (Traxler, 2007). 
The new generations of university students that have been born into what we know as the "Digital Age" are increasingly able to include technological devices, especially the smartphone, in their daily lives naturally and intuitively (García-Tormo, 2018). Similarly, the new possibilities of communication and access to immediate information enhance the possibility of instant access to a virtual world, increasing their ability to navigate the Internet without time or space limits, promoting the development of their social relations, promoting the creation and management of multimedia content, as well as facilitating the possibility of carrying out several activities simultaneously.

The particularities that make up the knowledge society lead us to reflect on how educational practice is developing at all levels and, especially, in the field of Higher Education, and whether it fits the characteristics, needs and concerns of students (Barroso \& Cabero, 2013; López-Noguero, 2008; López-Noguero et al., 2021). University teaching, and education in general, cannot escape this new reality that "has transformed the way students interact with their environment" (Artal et al., 2017, p.2), and has to offer teaching projects that adapt to the new emerging educational needs. Currently, university institutions are facing important socioeducational challenges, such as offering active teaching methodologies that integrate technology as a channeling element for learning, as well as the incorporation of educational perspectives, resources and dynamics that promote the collective construction of knowledge, participation, personal interaction and communication (Veytia et al., 2019).

Today, the smartphone is a mobile device increasingly present in university classrooms, becoming a technological tool that, if well used, could have great educational potential, due to the popularity of this technology, as well as its expansion, immediacy and accessibility. Smartphones offer immediate access to a wide information network, considering that the Internet has confirmed itself as the great global library that allows us to access an infinite amount of content of any kind. Referring to the academic world, the philosophy of Open Access "has begun to democratize knowledge and we now have access to millions of educational resources for all areas of knowledge" (Rovira-Collado, 2016, p. 2), since the Internet has become a leading educational tool.

Among the pedagogical trends that incorporate this technology in the processes of teaching, learning and evaluation in Higher Education, it has to be highlighted the so-called mobile learning. The mobile learning trend encourages students to use "a range of teaching resources and information sources that are not confined to the classroom or school but are distributed in different places outside the university environment" (Mancinas, 2018, p. 42).

O'Malley et al. (2003), define mobile learning as "any sort of learning that happens when the learner is not at a fixed, predetermined location, or learning that happens when the learner takes advantage of the learning opportunities offered by mobile technologies" (p. 6). UNESCO (2013) recognizes that mobile learning implies the use of mobile devices with the aim of facilitating formal and informal learning at any time and place. On the other hand, Traxler (2009) conceptualizes mobile learning as "the provision of education and training on PDAs / palmtops / handhelds, smartphones and mobile phones" (p. 2).

Other authors such as Baccari et al. (2016), understand mobile learning as an educational modality based on the interaction of students with their mobile devices in different contexts, with the aim of generating new ways of building learning. Faced with this emerging educational modality (Hinojo et al., 2020), the initiatives and perceptions of teachers and students have a transcendental role in the design and development of meaningful learning experiences, as well as in their evaluation (Kukulska-Hulme et al., 2009). And it is that, "the design of mobile learning activities should be driven by specific learning objectives. The use of (mobile) technology is not the target but rather a means to enable activities that were otherwise not possible, or to increase the benefits for the learners" (Sharples et al., 2009, p. 237).

The motivation generated by the use of smartphones in educational dynamics is very high, but it is necessary to start from a pedagogical framework of reference for the design of didactic activities and evaluation processes (Nikou \& Economides, 2021). A recent review of the current scientific literature, carried out by Fombona et al. (2020), reveals new areas of research and implementation of mobile learning such as, for example, the teaching of foreign languages, the appearance of social interaction methodologies, the evolution of forms of collaboration or the use of immersive and innovative virtual spaces in higher education. However, problems associated with the use of Smartphones in the classroom are also observed, such as the effect of collateral addiction, and their interference in the development of training activities.

Today's technology helps young university students to have unlimited access to information at their fingertips (Roig-Vila et al., 2021; France et al., 2021). Meanwhile, new pedagogical perspectives suggest that they should take on greater responsibility in their learning and the collaboration with their peers for the development of training activities. 
The use of smartphones in Higher Education contributes to the development of cognitive skills such as problem-solving, mediation, leading to critical and creative thinking and decision-making (Ramos et al., 2010). Other authors (Gallardo-López \& López-Noguero, 2020; Gikas \& Grant, 2013; Mohammed, 2020; SalcinesTalledo et al., 2020) analyze students' perceptions of learning with mobile devices and highlight that these devices favor interaction, collaboration and the creation and diffusion of educational content.

Al-Emran et al., (2016) and Hamidi \& Chavoshi (2018), delve into the question of student and teacher attitudes towards this type of technology integrated into the classroom, and the results obtained predicted that mobile learning could be one of the most promising pedagogical technologies that would be increasingly used in Higher Education environments. Moreover, works such as those by Murphy et al., (2014) or Saroia \& Gao (2019) are noteworthy contributions about how Higher Education students are using mobile devices to support their learning in an increasingly regular and progressive way.

In this sense, Qi (2019) analyses the relationship between academic performance and the use of smartphones in Higher Education, establishing a positive and beneficial relationship. However, this same author warns of the possible negative effects of the use of these devices by students, among which are the growing dependence and stress that they can generate. Other outstanding research works on this issue focus on exploring the phenomenon of Internet literacy and mobile learning about self-efficacy (Razzaq et al., 2018), problematic use of smartphones (Aranda et al., 2017; Horwood \& Anglim, 2021; Kil et al., 2021), or investigate how the use of smartphones influences the learning outcomes of university students (Arain et al., 2018; Hu \& Lai, 2019; Romero-Rodríguez et al., 2020).

There is a clear need to integrate digital tools into higher education methodologies, especially mobile devices, as they are highly conducive to ubiquitous learning and flexible, interconnected educational environments in which knowledge is produced and built (Cotán et al., 2021; Dafonte-Gómez et al., 2021; Fook et al., 2021; Paredes et al., 2019; Sevillano \& Vázquez, 2013; Zhao et al., 2010).

Furthermore, teaching methodologies that integrate ubiquity as an intrinsic element of the educational processes generate connectivity between all the agents involved in the development of learning. And they are coherent as they are adapted and contextualized to the social reality of new university students (Finogeev, 2020; Shishakly, 2019).

Integrating the smartphone into the daily reality of university classrooms is an opportunity to achieve greater equality of educational and social opportunities. It facilitates learning adapting the particular characteristics of each student, increasing productivity in the use of time and obtaining highly effective indicators for the assessments (González \& González, 2016; Reinoso, 2019; Salcines \& González, 2015), so it would be appropriate to take into account their potential. However, technologies should be designed and applied keeping in mind accessibility as a central concern, as their main goal has to be to remove the inequalities that they could bring, and, simultaneously, to serve as an instrument that extends the possibilities to all people, regardless of their buying power, geographic situation, age or gender (Gallardo-López, 2019).

From another angle, there are other studies that draw attention to the limitations of the use of mobile devices for learning that must also be considered. Scientists such as Traxler (2011) warn of the need to address issues such as the ethics of learning with mobile devices, especially when crossing the border between formal and informal learning. Other investigations, such as that of Parsons (2014), emphasize the importance of achieving a more fluid, adaptive, collaborative and exploratory learning, promoting the interrelation between formal and informal education. In this sense, Brazuelo et al. (2017) indicate as the main difficulties or barriers those related to educational regulations on restrictions on the use of smartphones in classrooms, the lack of awareness of students about the educational usefulness of their mobile phones and ignorance, on the part of the students. teachers, of the educational potential of these mobile devices. On the other hand, other authors focus on analyzing the impact generated by the use of the smartphone on the written communication of students, taking into account grammatical aspects and linguistic expression (Gómez \& Gómez, 2015; Torrado-Cespón, 2015). In this research we address, the general objective is to analyze how students make use of their smartphones in university contexts and how they evaluate the use of these mobile devices as educational tools.

\section{Methodology}

The research methodology used responds to an ex post facto, quantitative, transversal, correlational and descriptive design.

From the general research objective, two research questions are posed: 
1) How do students use their smartphones in different educational activities in the university context?

2) How do students evaluate the use of smartphones, as an educational tool, in university academic dynamics?

\subsection{Contextualization}

The research is contextualized in the city of Seville, located in the south of Spain. Specifically, at the Pablo de Olavide University, a public university that was founded in 1997 and which has seven centers that teach their degrees on campus, plus the affiliated "San Isidoro de Sevilla" university center.

The study takes place during the first semester of the 2018/2019 academic year, promoted by professors from the Department of Education and Social Psychology and involving students from the Faculty of Social Sciences. According to data from the academic report 2018/2019 (Pablo de Olavide University, 2019), the university had a total of 9,813 undergraduate and double degree students. In the Degree in Social Education, 247 students were enrolled, 705 in the Degree in Social Work and 305 in the Double Degree in Social Work and Social Education. The origin of the students is mostly national, although the university supports and facilitates academic mobility through various programs, the most prominent being the ERASMUS Program, which received 545 students in the 2018/2019 academic year.

\subsection{Characteristics and selection of the sample}

The sample selected for the study is 252 , representing $20 \%$ of the total population (Pablo de Olavide University, 2019). To determine significant sample size, the following calculation formula for finite populations has been used (Arnal et al., 1992):

$$
n=\frac{N * Z_{\alpha}^{2} * p * q}{d^{2} *(N-1)+Z_{\alpha}^{2} * p * q}
$$

$\mathrm{N}=$ total population

$\mathrm{d}=$ maximum acceptable error (in this case $3 \%=0.03$ )

$z=1,96$ (statistical confidence level 95\%)

$p^{*} q=$ expected proportion; $p=(5 \%): 0,05 ; q=1-p(1-0.05=0.95)$

$$
n=\frac{1257 *(1,96)^{2} * 0,05 * 0,95}{(0,03)^{2} *(1257-1)+(1,96)^{2} * 0,05 * 0,95}=175,09=175
$$

The final sample has well-defined characteristics, composed of 211 women (83.7\%) and 41 men (16.3\%). Looking at the age ranges, it highlights that $38.1 \%$ are under 20 years old, $52.8 \%$ are between 20 and 25 years old and $9.1 \%$ are over 25 years old.

Paying attention to the studies one can assert that the participants are enrolled in, $10.75 \%$ are enrolled in the Degree of Social Education, $71.4 \%$ in Social Work and $17.9 \%$ in the Double Degree of Social Work and Social Education. Besides, $59.5 \%$ of those surveyed belonged to the first year, $7.9 \%$ to the second year, $6.7 \%$ to the third year, and $25.8 \%$ to the fourth year of their respective studies.

\subsection{Instrument}

To collect the data, the questionnaire "Smartphone and University Questionnaire. Student Perspective. SUQS" by Salcines-Talledo \& González-Fernández (2015) was used. The instrument was submitted by the authors to content validity, construct validity and reliability tests, obtaining valid and reliable results regarding its use to collect significant and relevant information about the university student's vision of the pedagogical implementation of the smartphone in Higher Education contexts. The instrument's internal consistency, calculated with Cronbach's Alpha, was .97, thereby showing the high reliability of the tool. Likewise, the KMO test provided a value of .835 , indicating a high relationship between the variables as it is close to 1 , and Bartlett 
sphericity test $\left(x^{2}=3704.693 ; \mathrm{gl}=300 ; \mathrm{p}<.000\right)$ also indicated the adequacy of the factorial analysis carried out.

The questionnaire is segmented into three thematic blocks and nine study dimensions, some of which are subdivided into various analysis categories, as shown in Table 1. The response format is Likert type with ordinal scores ranging from 1 to 4 . Specifically, for items in Block 2, 1 is "strongly disagree" and 4 "completely agree"; and for items in Block 3, 1 is "null" and 4 "total". In the case of Block 1, identification data was collected with multiple responses of a nominal type.

This instrument has been used in other high-impact scientific research (Salcines-Talledo \& GonzálezFernández, 2020; Salcines-Talledo et al., 2020), demonstrating its usefulness and relevance for this type of study.

Table 1

Structure of the questionnaire "Smartphone and University Questionnaire. Student Perspective. SUQS"

\begin{tabular}{lllr}
\hline \multicolumn{1}{c}{ Blocks } & \multicolumn{1}{c}{ Dimensions } & Subdimensions & \multicolumn{1}{c}{$\begin{array}{c}\text { Number of } \\
\text { items }\end{array}$} \\
\hline 1. Identification data & & & 10 \\
\hline 2. General smartphone & & Knowledge & 5 \\
\cline { 2 - 4 } questions & Use & Place of use & 7 \\
\cline { 2 - 4 } & & Frequency of use & 8 \\
\cline { 2 - 4 } & Importance & & 5 \\
\cline { 2 - 3 } & Guided introduction of the smartphone in the & Benefits & 8 \\
\cline { 2 - 3 } & teaching, learning and evaluation processes & Difficulties & \\
\cline { 2 - 3 } & & &
\end{tabular}

\begin{tabular}{|c|c|c|c|}
\hline & \multirow{2}{*}{$\begin{array}{l}\text { Introduction of the smartphone into the } \\
\text { teaching, learning and evaluation processes } \\
\text { on your initiative }\end{array}$} & Benefits & 8 \\
\hline & & Difficulties & 6 \\
\hline & \multicolumn{2}{|l|}{ Training } & 7 \\
\hline \multirow{9}{*}{$\begin{array}{l}\text { 3. Questions about } \\
\text { smartphone } \\
\text { applications }\end{array}$} & \multirow[t]{3}{*}{ Application knowledge } & Communication & 5 \\
\hline & & $\begin{array}{l}\text { Management and } \\
\text { organization }\end{array}$ & 7 \\
\hline & & $\begin{array}{l}\text { Teaching/Learning/ } \\
\text { Evaluation }\end{array}$ & 14 \\
\hline & \multirow[t]{3}{*}{ Application use } & Communication & 5 \\
\hline & & $\begin{array}{l}\text { Management and } \\
\text { organization }\end{array}$ & 7 \\
\hline & & Teaching/Learning/Evaluation & 14 \\
\hline & \multirow[t]{3}{*}{ Importance of applications } & Communication & 5 \\
\hline & & $\begin{array}{l}\text { Management and } \\
\text { organization }\end{array}$ & 7 \\
\hline & & Teaching/Learning/Evaluation & 14 \\
\hline
\end{tabular}

Source: Salcines-Talledo \& González-Fernández (2015)

The instrument was adapted in the survey administration app "Google Forms" and distributed through the university's virtual classroom and by email to the sample under study. The Statistical Package for the Social Sciences (SPSS V26) software was used for carrying out descriptive and correlational analyzes.

\section{Results and Discussion}

\subsection{General questions about smartphones and their applications}

Analyzing the results obtained on the study dimension "knowledge", in general terms, $73.8 \%$ of those surveyed expressed knowledge about useful smartphone applications for their academic activity and, consequently, $26.2 \%$ were unaware of this type of application in the university environment. There is an important percentage of students that do not use applications due to ignorance of them and it could help them greatly in their university career. 
Regarding the academic use of smartphones in situ, the data shows that only $34.2 \%$ of those surveyed admitted having used their smartphone during a professor's lecture in class (item 6), although $81.7 \%$ indicated that they had used their smartphone in the development of cooperative learning activities (item 8). Therefore, it can be seen that the majority of students surveyed can use mobile devices in their face-to-face sessions at the university even occasionally.

Focusing on item 9, which corresponds to the use given to the smartphone to develop the activities related to the practical part of the subjects, we can see that the average for this item 9 is close to 3 (2.75), which indicates that, in general terms, the students use the mobile device for this type of tasks mainly for research information and maintain contact between students, among others.

Specifically for the dimension "importance of smartphones in the university", $69.8 \%$ of the students recognize that the use of the smartphone by teachers is important for teaching (item 10), 75\% admit that it is important for learning (item 11), 98.4\% indicate the importance for academic management and organization (item 12), $92.8 \%$ consider it important for communication with colleagues (item 13) and $95.2 \%$ express that the university needs to provide the resources to make the use of smartphones in university classrooms possible (item 14). All these numerical data clearly show the positive opinion of the surveyed subjects about the introduction of intelligent devices in the dynamics of the university academic organization and its teaching-learning processes. To the question of whether the student has had any formative experience in which the professor has set the introduction of the smartphone in the processes of teaching, learning and assessment of university education, $53.57 \%$ indicate that they have and $46.43 \%$ declare that they have not had any experience in this sense, promoted at the time by professors, so it can be inferred that there is still a long way to go for teaching innovation in this type of issues.

Mobile devices such as smartphones can provide great benefits to students, who are fully aware of this fact. In this sense, the data collected about the benefits that the use of the smartphone in the university provides shows that $97.2 \%$ of those surveyed indicate that it allows them to quickly search for information (item 16), with an average very close to 4 .

$96.9 \%$ of students acknowledged that the use of the smartphone allowed them to access the content at any time and place (item 17), and gave them more security when studying and doing assignments (91.2\%) since it allowed them to contact the professor and their classmates outside the classroom (item 18). This question of ubiquity is fundamental when referring to the advantages and benefits of devices such as the smartphone, which are perfectly known by the students surveyed.

In addition to this, and referring to difficulties and problems caused by these technologies, with regards to the study dimension "difficulties in the use of the smartphone at university", $66.3 \%$ of the sample are dependent on these devices (item 19), while $63.1 \%$ find it difficult to select the information that is accessible in excess (item 20) and, finally, 87.3\% think that it does not hurt their written expression (item 21).

Finally, when they were asked if they would like to receive specific training on how to take advantage of the smartphone in learning activities (item 22), 88.5\% answer positively, where the average for this item is 3.29 . The results of this item clearly show the need for universities to provide training in digital skills, especially in mobile devices and their possibilities in the area of teach.

Table 2

Descriptive statistics Block 2. General questions about smartphones

\begin{tabular}{|c|c|c|c|c|c|c|}
\hline Dimension & Item & Average & Standard Deviation & Variance & Asymmetry & Kurtosis \\
\hline Knowledge & 5 & 2.89 & .76 & .57 & -.41 & .014 \\
\hline \multirow[t]{3}{*}{ Use } & 6 & 2.12 & .85 & .73 & .20 & -.82 \\
\hline & 8 & 3.04 & .87 & .77 & -.89 & .33 \\
\hline & 9 & 2.75 & .94 & .88 & -.48 & -.58 \\
\hline \multirow[t]{5}{*}{ Importance } & 10 & 2.78 & .71 & .51 & -.37 & .14 \\
\hline & 11 & 2.94 & .73 & .54 & -.31 & -.15 \\
\hline & 12 & 3.70 & .50 & .25 & -1.61 & 2.86 \\
\hline & 13 & 3.63 & .66 & .44 & -1.86 & 3.23 \\
\hline & 14 & 3.63 & .62 & .39 & -1.89 & 3.95 \\
\hline \multirow[t]{3}{*}{ Benefits } & 16 & 3.71 & .55 & .31 & -2.18 & 5.79 \\
\hline & 17 & 3.73 & .56 & .32 & -2.56 & 7.66 \\
\hline & 18 & 3.46 & .69 & .48 & -1.19 & 1.14 \\
\hline \multirow[t]{3}{*}{ Difficulties } & 19 & 2.81 & .76 & .58 & -.13 & -.44 \\
\hline & 20 & 2.74 & .80 & .65 & -.17 & -.46 \\
\hline & 21 & 1.81 & .74 & .55 & .85 & .85 \\
\hline Training & 22 & 3.29 & .70 & .50 & -.74 & .32 \\
\hline
\end{tabular}


Likewise, this questionnaire dedicates a block of questions about the level of knowledge, use and importance given by the surveyed students to different applications for smartphones related to the university academic activity.

Significant data about the use and importance that respondents assign to mobile applications related to email, instant messaging, social networking, cloud file hosting, as well as the use of calendars for the management and organization of academic activity, which escape the purpose of this article were found.

The data obtained, after the Kolmogorov-Smirnov test, did not meet the assumption of normal probability distribution, so non-parametric statistics were used in the data treatment. Specifically, the Spearman Rho test was performed for multiple comparisons, considering a $p$ value less than or equal to .05 to establish statistical significance.

\subsection{Spearman's rank correlation coefficient}

The statistical data obtained were subjected to variable correlation tests, to know if there is significant evidence that indicates a relationship between the different responses obtained in each of the dimensions of study. The results of the Spearman correlation test applied to the different items of interest for the research at hand are presented below (Table 3).

\section{Table 3}

Spearman's rank correlation coefficient

\begin{tabular}{|c|c|c|c|}
\hline & & \multicolumn{2}{|c|}{ Spearman's rho } \\
\hline Reference item & Cross item & $\begin{array}{l}\text { Correlation } \\
\text { coefficient }\end{array}$ & $\begin{array}{l}\text { Significance } \\
\text { (bilateral) }\end{array}$ \\
\hline \multirow{2}{*}{ It generates dependency } & $\begin{array}{l}\text { It allows me to access the content at any } \\
\text { time and place }\end{array}$ & .739 & $.018\left(^{*}\right)$ \\
\hline & $\begin{array}{l}\text { The excess of accessible information makes } \\
\text { it difficult for me to select it }\end{array}$ & .678 & $.000\left(^{\star \star}\right)$ \\
\hline \multirow{2}{*}{$\begin{array}{l}\text { I would like to receive specific } \\
\text { training on how to use the } \\
\text { Smartphone in learning activities }\end{array}$} & $\begin{array}{l}\text { The use of the Smartphone is important for } \\
\text { learning }\end{array}$ & .712 & $.007\left({ }^{* *}\right)$ \\
\hline & $\begin{array}{l}\text { The use of the Smartphone is important for } \\
\text { academic management and organization }\end{array}$ & .688 & $.003\left({ }^{* *}\right)$ \\
\hline \multirow{3}{*}{$\begin{array}{l}\text { I know useful Smartphone } \\
\text { applications for my academic } \\
\text { activity }\end{array}$} & It allows me a quick search for information & .785 & $.003(* *)$ \\
\hline & $\begin{array}{l}\text { It allows me to access the content at any time } \\
\text { and place }\end{array}$ & .680 & $.004\left({ }^{* \star}\right)$ \\
\hline & $\begin{array}{l}\text { It gives me more security when studying and } \\
\text { doing work by allowing contact with the } \\
\text { teacher and with classmates outside the } \\
\text { classroom }\end{array}$ & .758 & $.012\left(^{*}\right)$ \\
\hline
\end{tabular}

note: ${ }^{*}=$ significance at $0.05 ;{ }^{* *}=$ significance at 0.01

The results give us different relevant aspects of the proposed research goal, although before its presentation it must be considered: a) That all the correlations were positive, which means that when high scores are given in one variable, they are also high in the other one; b) That the correlations were, for the most part, significant at a significance level of 0.01 and considered "high"(Etxeberria \& Tejedor, 2005; Hedges, 1981).

The dependence generated by the use of the smartphone in university educational contexts is directly related to the ease of access to content at any time and place (.739), including the difficulty in selecting reliable and valid information from the vast amount of content that it provides Internet (.678).

Beside this. students demand training to optimize the use of their smartphones in Higher Education contexts since they consider it an important tool for learning (.712) and academic management and organization (.688). 
Also, students who claim to know a greater number of useful applications for their academic activity, acknowledge that they use them because it allows them to quickly search for information (.785), access content without space or time limitations (.680) and because it gives you more security when doing activities and work, mainly because the smartphone facilitates contact between colleagues and teachers (.758).

\subsection{Results differentiated by sex, age, university degree, and academic year}

To delve further into the possible relationships between the variables sex, age, university degree and academic year, with the results obtained in the research, different tables were crossed and remarkable results were obtained.

Knowing the academic year in which the subject is enrolled and the item "use of the smartphone during a master lesson" (Table 4), it can be appreciated that the third-year students show a lower use of the smartphone during a master class, compared to the other courses.

Slightly higher use of applications during a master class by first-year students $(36 \%)$ is highlighted. This issue may be because they have not had the experience of using the smartphone in the dynamics of classes in some of the few subjects that may have been taken.

\section{Table 4}

Variable's Crossing "Course enrolled in" and "Use of the smartphone during a master lesson"

\begin{tabular}{|c|c|c|c|c|c|c|c|}
\hline & & & \multicolumn{4}{|c|}{ Using your smartphone during a masterclass } & \multirow[b]{2}{*}{ Total } \\
\hline & & & 1 & 2 & 3 & 4 & \\
\hline \multirow[t]{10}{*}{ Course enrolled in } & 10 & $\mathrm{n}$ & 35 & 61 & 47 & 7 & 150 \\
\hline & & $\%$ & $23.3 \%$ & $40.7 \%$ & $31.3 \%$ & $4.7 \%$ & $100 \%$ \\
\hline & $2^{0}$ & $\mathrm{n}$ & 4 & 9 & 4 & 3 & 20 \\
\hline & & $\%$ & $20 \%$ & $45 \%$ & $20 \%$ & $15 \%$ & $100 \%$ \\
\hline & $3^{0}$ & $\mathrm{n}$ & 3 & 11 & 3 & 0 & 17 \\
\hline & & $\%$ & $17.6 \%$ & $64.7 \%$ & $17.6 \%$ & $0 \%$ & $100 \%$ \\
\hline & $4^{0}$ & $\mathrm{n}$ & 26 & 17 & 21 & 1 & 65 \\
\hline & & $\%$ & $40 \%$ & $26.2 \%$ & $32.3 \%$ & $1.5 \%$ & $100 \%$ \\
\hline & Total & $\mathrm{n}$ & 68 & 98 & 75 & 11 & 252 \\
\hline & & $\%$ & $27 \%$ & $38.9 \%$ & $29.8 \%$ & $4.4 \%$ & $100 \%$ \\
\hline
\end{tabular}

Looking at the age groups of the sample under study, it is noted how students under 20 years old recognize a greater use of the smartphone during the development of cooperative learning activities (Table 5). This may indicate that younger students, true digital natives, are more likely to use applications to contact other peers and communicate to work on different academic activities in a group setting, naturally integrating ubiquitous learning. The same circumstance could occur with the use of the smartphone in the development of individual practical activities (Figure 1).

\section{Table 5}

Variable's Crossing "Age" and "Use of the smartphone during the development of cooperative learning activities"

\begin{tabular}{|c|c|c|c|c|c|c|c|}
\hline & & & \multicolumn{4}{|c|}{$\begin{array}{l}\text { Using the smartphone during cooperative learning } \\
\text { activities }\end{array}$} & \multirow[b]{2}{*}{ Total } \\
\hline & & & 1 & 2 & 3 & 4 & \\
\hline \multirow[t]{8}{*}{ Age } & Under 20 years & $\mathrm{n}$ & 2 & 7 & 55 & 32 & 96 \\
\hline & old & $\%$ & $2.1 \%$ & $7.3 \%$ & $57.3 \%$ & $33.3 \%$ & $100 \%$ \\
\hline & From 20 to 25 & $\mathrm{n}$ & 14 & 14 & 66 & 39 & 133 \\
\hline & years old & $\%$ & $10.5 \%$ & $10.5 \%$ & $49.6 \%$ & $29.3 \%$ & $100 \%$ \\
\hline & More than 25 & $\mathrm{n}$ & 7 & 2 & 6 & 8 & 23 \\
\hline & years & $\%$ & $30.4 \%$ & $8.7 \%$ & $26.1 \%$ & $34.8 \%$ & $100 \%$ \\
\hline & Total & $\mathrm{n}$ & 23 & 23 & 127 & 79 & 252 \\
\hline & & $\%$ & $9.1 \%$ & $9.1 \%$ & $50.4 \%$ & $31.3 \%$ & $100 \%$ \\
\hline
\end{tabular}




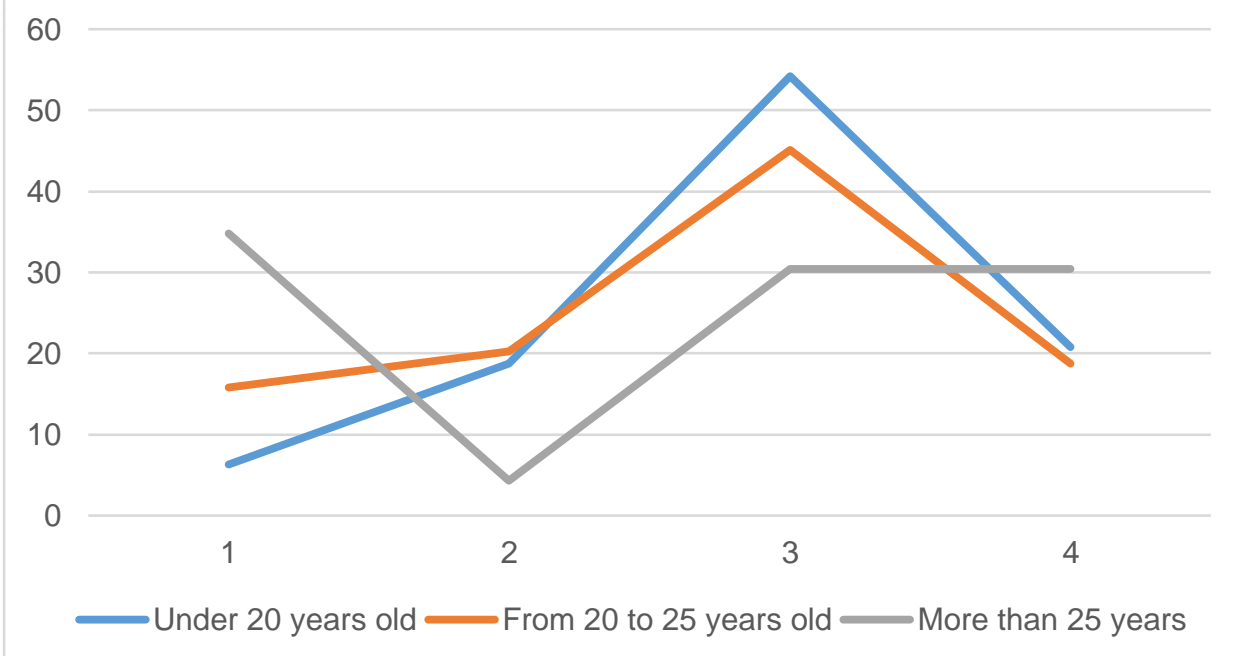

Figure 1. Variable's Crossing "Age" and "Use of the smartphone in the development of individual practical activities". Response rate.

In any case, on the use of the smartphone to manage and organize everything related to academic activities, the students aged 25 and under use the smartphone for academic management and organization to a greater extent (Table 6). In this sense, although those over 25 years old give high scores in this item, it stands out that $4.3 \%$ of them have stated that they do not use the smartphone in any way for the management and organization of their university tasks.

Table 6

Variable's Crossing "Age" and "Use of the smartphone for academic management and organization"

\begin{tabular}{|c|c|c|c|c|c|c|c|}
\hline & & & Using the & one fol & manage & rganization & \\
\hline & & & 1 & 2 & 3 & 4 & Total \\
\hline Age & Under 20 years old & $\mathrm{n}$ & 0 & 1 & 23 & 72 & 96 \\
\hline & & $\%$ & $0 \%$ & $1 \%$ & $24 \%$ & $75 \%$ & $100 \%$ \\
\hline & From 20 to 25 years old & $n$ & 0 & 2 & 33 & 98 & 133 \\
\hline & & $\%$ & $0 \%$ & $1.5 \%$ & $24.8 \%$ & $73.7 \%$ & $100 \%$ \\
\hline & More than 25 years & $\begin{array}{l}\mathrm{n} \\
\%\end{array}$ & $\begin{array}{c}1 \\
4.3 \%\end{array}$ & $\begin{array}{c}0 \\
0 \%\end{array}$ & $\begin{array}{c}10 \\
435 \%\end{array}$ & $\begin{array}{c}12 \\
522 \%\end{array}$ & $\begin{array}{c}23 \\
100 \%\end{array}$ \\
\hline & Total & $\begin{array}{l}\mathrm{n} \\
\%\end{array}$ & $\begin{array}{c}1 \\
0.4 \%\end{array}$ & $\begin{array}{c}3 \\
1.2 \%\end{array}$ & $\begin{array}{c}66 \\
26.2 \%\end{array}$ & $\begin{array}{c}182 \\
72.2 \%\end{array}$ & $\begin{array}{c}252 \\
100 \%\end{array}$ \\
\hline
\end{tabular}

Referring to the psychological support or the security that the use of mobile devices can mean for the students consulted, $26 \%$ of those over 25 years old indicate that using the smartphone does not give them more security when studying and doing work in contact with the teacher and with their colleagues outside the classroom (Figure 2). 


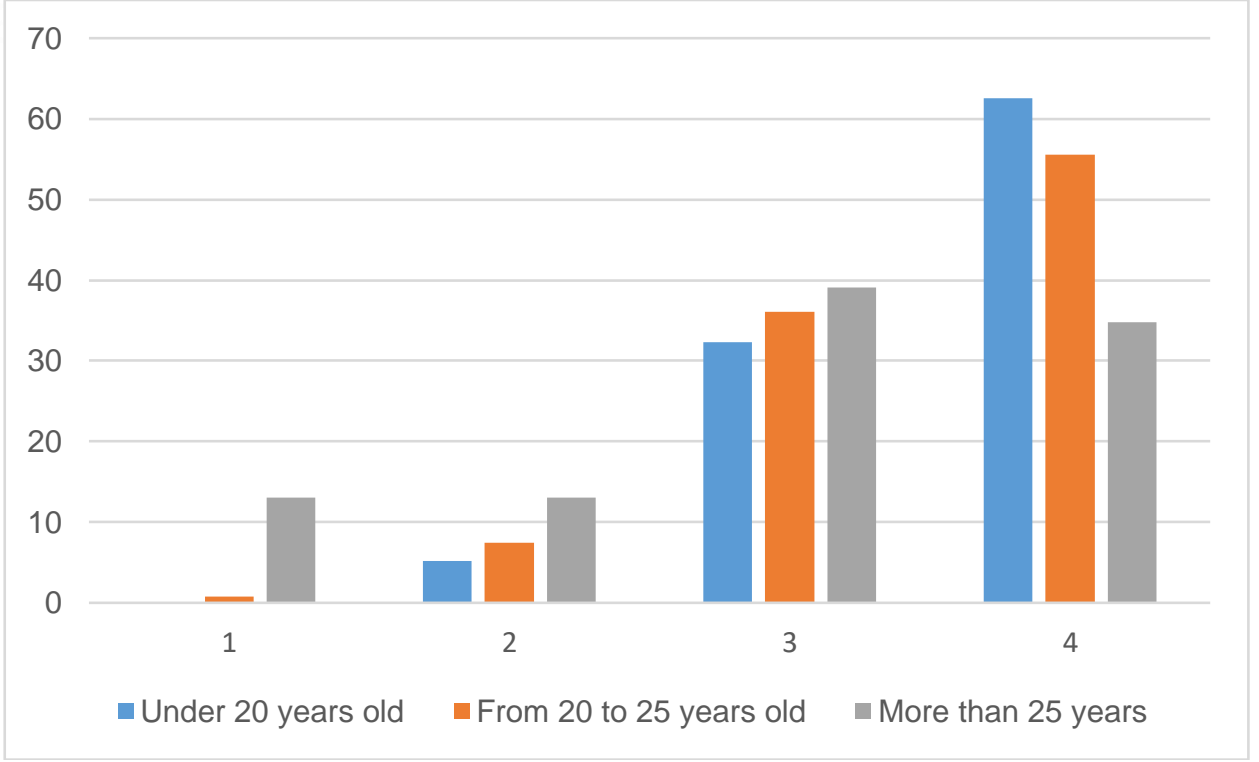

Figure 2. Variable's Crossing "Age" and "Using the smartphone gives me more security when studying and doing work by allowing contact with the teacher and with colleagues outside the classroom". Response rate

Again, it is a trend detected repeatedly in the interpretation of the data from this questionnaire, we can see how the younger generations, use the smartphone more in the university and understand that it is a technological tool that facilitates, largely, the educational processes that occur in Higher Education.

In this regard, it is interesting to analyze how the ubiquity provided by mobile devices influences positively the establishment of relationships between all those involved in the educational process, improving contact without temporal or spatial limitations.

Going further, attending to the question of whether the use of the smartphone can harm students' written expression, a clear differentiation by age group on this issue is shown. Students over 25 years old are much more aware of their reading and writing limitations caused by the massive use of devices, and they believe that using the smartphone has an impact on their way of expressing themselves in writing (Table 7).

\section{Table 7}

Variable's Crossing "Age" and "Using the smartphone harms my written expression"

\begin{tabular}{|c|c|c|c|c|c|c|c|}
\hline & & & \multicolumn{4}{|c|}{ Using the smartphone harms my written expression } & \multirow[b]{2}{*}{ Total } \\
\hline & & & 1 & 2 & 3 & 4 & \\
\hline \multirow[t]{8}{*}{ Age } & Under 20 years old & $\mathrm{n}$ & 34 & 47 & 11 & 4 & 96 \\
\hline & & $\%$ & $35.4 \%$ & $49 \%$ & $11.5 \%$ & $4.2 \%$ & $100 \%$ \\
\hline & From 20 to 25 years old & $\mathrm{n}$ & 53 & 72 & 6 & 2 & 133 \\
\hline & & $\%$ & $39.8 \%$ & $54.1 \%$ & $4.5 \%$ & $1.5 \%$ & $100 \%$ \\
\hline & More than 25 years & $n$ & 2 & 12 & 6 & 3 & 23 \\
\hline & & $\%$ & $8.7 \%$ & $52.2 \%$ & $26.1 \%$ & $13 \%$ & $100 \%$ \\
\hline & Total & $n$ & 89 & 131 & 23 & 9 & 252 \\
\hline & & $\%$ & $35.3 \%$ & $52 \%$ & $9.1 \%$ & $3.6 \%$ & $100 \%$ \\
\hline
\end{tabular}

Depending on the type of studies the student is taking, a significant differentiation shows in the responses corresponding to whether they have had formative experiences in which the teacher has guided the introduction of the smartphone in the teaching, learning and assessment processes (Figure 3). In this sense, we can see how the students of the Degree in Social Education stand out especially, with $71.4 \%$ of the affirmative answers in this question. 


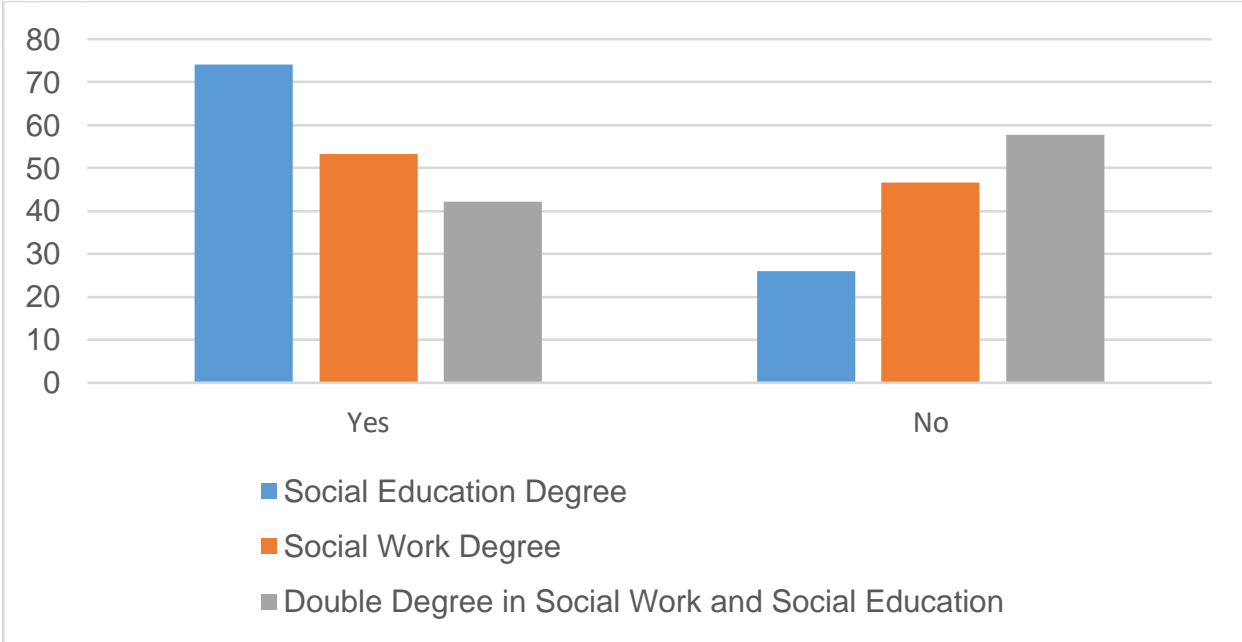

Figure 3. Variable's Crossing "Type of studies" and "Formative experience in which the teacher has set out to introduce the smartphone into the teaching, learning and assessment processes". Response rate.

Thus, all students of the Degree in Social Education say that using the smartphone allows them to access the content at anytime and anywhere, taking advantage of the many benefits of ubiquity provided by these devices, and following the trends towards the ubiquity of the teaching-learning processes in virtual contexts (Table 8). However, some students from the other degree studies consulted have indicated that their mobile phones do not always clearly allow good access to content in all circumstances and locations, specifically $3.3 \%$ in Social Work Degree and $4.4 \%$ in the Double Degree in Social Work and Social Education.

\section{Table 8}

Variable's Crossing "Type of studies being undertaken" and "The smartphone allows me to access content anytime and anywhere"

\begin{tabular}{|c|c|c|c|c|c|c|c|}
\hline & & & \multicolumn{4}{|c|}{$\begin{array}{l}\text { The smartphone allows me to access content } \\
\text { anytime and anywhere }\end{array}$} & \multirow[b]{2}{*}{ Total } \\
\hline & & & 1 & 2 & 3 & 4 & \\
\hline \multirow{8}{*}{$\begin{array}{l}\text { Course } \\
\text { enrolled in }\end{array}$} & Social Education Degree & $\mathrm{n}$ & 0 & 0 & 11 & 16 & 27 \\
\hline & & $\%$ & $0 \%$ & $0 \%$ & $40.7 \%$ & $59.3 \%$ & $100 \%$ \\
\hline & Social Work Degree & $\mathrm{n}$ & 2 & 4 & 32 & 142 & 180 \\
\hline & & $\%$ & $1.1 \%$ & $2.2 \%$ & $17.8 \%$ & $78.9 \%$ & $100 \%$ \\
\hline & Double Degree in Social Work & $\mathrm{n}$ & 2 & 0 & 4 & 39 & 45 \\
\hline & and Social Education & $\%$ & $4.4 \%$ & $0 \%$ & $8.9 \%$ & $86.7 \%$ & $100 \%$ \\
\hline & Total & $\mathrm{n}$ & 4 & 4 & 47 & 197 & 252 \\
\hline & & $\%$ & $1.6 \%$ & $1.6 \%$ & $18.7 \%$ & $78.2 \%$ & $100 \%$ \\
\hline
\end{tabular}

\section{Conclusions}

The research carried out aimed to analyze how students make use of their smartphones in university contexts and how they evaluate their educational usefulness.

The results obtained show that new generations of university students who visit our classrooms know and use very diverse applications on their smartphones that can be very useful for developing their academic activities (García-Tormo, 2018; Fook et al., 2021; Roig-Vila et al., 2021), where cooperative learning is highlighted (Cotán et al., 2021).

These devices greatly help to developed educational interpersonal relationships among students, building knowledge in a systematic and coordinated manner (Gallardo-López \& López-Noguero, 2020). On this issue, a preferential use by younger students, considered digital natives, accustomed to include technologies in different areas of their lives, including the university academic environment.

However, the use of smartphones in the classroom by some professors continues to experience certain reticence and resistance, especially during lectures. Nevertheless, there are notable changes that encourage 
the development of more practical activities that use these technologies, for example investigative projects, applicability of knowledge, or acquisition of skills for teamwork. (Saroia \& Gao, 2019; France et al., 2021). According to the results obtained in the research, university students show a clear positive evaluation of the introduction of the smartphone in the academic activities that take place in Higher Education (Salcines-Talledo et al., 2020; Salcines-Talledo \& González-Fernández, 2020). In this sense, they find numerous advantages for the search of information and access without physical or time limitations, better management of their academic activities and responsibilities, to improve communication with other students and to enhance learning, giving them more security when facing learning activities (Saroia \& Gao, 2019). Research results suggest that younger students use the smartphone the most at the university level.

Also, a high percentage of students recognizes the importance of professors using the smartphone as part of teaching methodology (Sharples et al., 2009), confirming the prevailing need for university institutions to provide structural support and learning resources to be able to access these devices properly. In this sense, the analysis of the data obtained in the research confirms that the surveyed students demand better resources and means from Higher Education institutions for the use of this mobile technology in their academic environments. On the other hand, the negative aspects of using the smartphone include the dependence, in terms of frequency and habits of use, interference with daily life, or abstinence and stress, that this technology may create (Aranda et al., 2017; Fombona et al., 2020), as well as the uncertainty that it can create when selecting the enormous amount of information that is offered online (Qi, 2019; Horwood \& Anglim, 2021; Kil et al., 2021). In addition, regarding the possibility that the use of the smartphone could harm the written expression of students Gómez \& Gómez, 2015; Torrado-Cespón, 2015), the results obtained highlight that it is the older students who, to a greater extent, believe that it has a negative impact on their written communication.

It is therefore essential to favor the use of technologies such as smartphones in university classrooms, but also to train the student in the rational use of these mobile devices, and to do this, the involvement of professors is necessary (Kukulska-Hulme et al., 2009; Traxler, 2011), still reluctant to use it in their teaching dynamics.

As the main limitations of the study carried out, it is necessary to specify that the results of this research cannot be extrapolated to a national or international reality, due to the size of the sample and the contextualization of the research. Therefore, as a future line of research, it is intended to increase the sample with students from other degrees from various national and international universities.

Likewise, one could go deeper into aspects such as the possibilities of mobile learning for the teaching of foreign languages, new methodologies of social interaction with mobile devices, or new ways of using virtual spaces for the development of teaching-learning.

\section{References}

Al-Emran, M; Elsherif, H. M. \& Shaalan, K. (2016). Investigating attitudes towards the use of mobile learning in higher education. Computers in Human Behavior, 56, 93-102. https://doi.org/10.1016/j.chb.2015.11.033

Arain, A.A; Hussain, Z; Rizvi, W.H. \& Vighio, M.S. (2018). An analysis of the influence of a mobile learning application on the learning outcomes of higher education students. Universal Access in the Information Society, 17(2), 325-334. https://doi.org/10.1007/s10209-017-0551-y

Aranda López, M; Fuentes Gutiérrez, V. \& García-Domingo, M. (2017). "No sin mi Smartphone": Elaboración y validación de la Escala de Dependencia y Adicción al Smartphone (EDAS). Terapia psicológica, 35(1), 35-45. https://dx.doi.org/10.4067/S0718-48082017000100004

Arnal, J; Del Rincón, D. \& Latorre, A. (1992). Investigación educativa. Fundamentos y metodología. Barcelona: Labor.

Artal, J. S; Casanova, O; Serrano, R. M. \& Romero, E. (2017). Dispositivos móviles y Flipped Classroom. Una experiencia multidisciplinar del profesorado universitario. Edutec. Revista Electrónica De Tecnología Educativa, 59, 1-13. https://doi.org/10.21556/edutec.2017.59.817

Baccari S., Mendes F., Nicolle C., Soualah-Alila F. \& Neji M. (2016) A Comparative Study of the Mobile Learning Approaches. In: Boumerdassi S., Renault É., Bouzefrane S. (eds) Mobile, Secure, and Programmable Networking. MSPN 2016. Lecture Notes in Computer Science, vol 10026. Springer, Cham. https://doi.org/10.1007/978-3-31950463-6 7.

Barroso, J. \& Cabero, J. (2013). Nuevos escenarios digitales. Las tecnologías de la información y la comunicación aplicadas a la formación y desarrollo curricular; Pirámide: Madrid, España.

Brazuelo F; Gallego, D. J. \& Cacheiro, M. L. (2017). Los docentes ante la integración educativa del teléfono móvil en el aula. RED. Revista de Educación a Distancia, 5, 1-22. http://dx.doi.org/10.6018/red/52/6

Cotán, A; García-Lázaro, I; \& Gallardo-López, J. A. (2021). Trabajo colaborativo en línea como estrategia de aprendizaje en entornos virtuales: una investigación con estudiantes universitarios de Educación Infantil y Educación Primaria. Educación, 30(58), 147-168. https://doi.org/10.18800/educacion.202101.007 
Dafonte-Gómez, A; Maina, M.F. \& García-Crespo, O. (2021). Uso del smartphone en jóvenes universitarios: Una oportunidad para el aprendizaje. Pixel-Bit, Revista de Medios y Educación, 60, 211-227. https://doi.org/10.12795/pixelbit.76861

Etxeberria, J. \& Tejedor, J. (2005). Análisis descriptivo de datos en educación. La Muralla: Madrid, España.

Finogeev, A; Gamidullaeva, L; Bershadsky, A; Fionova, L; Deev, M. \& Finogeev, A. (2020). Convergent approach to synthesis of the information learning environment for higher education. Education and Information Technologies, 25(1), 11-30. https://doi.org/10.1007/s10639-019-09903-5

Fombona, J; Pascual, M. A. \& Pérez Ferra, M. (2020). Analysis of the Educational Impact of M-Learning and Related Scientific Research. Journal of New Approaches in Educational Research, 9(2), 167-180. https://doi.org/10.7821/naer.2020.7.470

Fook, C.Y; Narasuman, S; Aziz, N.A; Mustafa, S.M.S. \& Han, C.T. (2021). Smartphone Usage among University Students. Asian Journal of University Education, 17(1), 283-291. https://doi.org/10.24191/ajue.v17i1.12622

France, D; Lee, R; Maclachlan, J. \& McPhee, S.R. (2021). Should you be using mobile technologies in teaching? Applying a pedagogical framework. Journal of Geography in Higher Education, 45(2), 221-237. https://doi.org/10.1080/03098265.2020.1773417

Gallardo-López, J.A. (2019). Accesibilidad a la cultura audiovisual para personas con discapacidad sensorial. In Ramírez Paredes, K.G. (Ed.). Recursos educativos para el aula del siglo XXI (pp.11-19). Adaya Press: Eindhoven, Netherlands.

Gallardo-López, J.A. \& López-Noguero, F. (2020). Twitter como recurso metodológico en Educación Superior: Una experiencia educativa con estudiantes de Trabajo Social. Alteridad, 15(2), 174-189. https:// doi.org/10.17163/alt.v15n2.2020.03

Gallardo-López, J. A; López-Noguero, F. y Pedrero-García, E. (2021). El uso del smartphone en Enseñanza Superior ante nuevos escenarios sociales y digitales. Una investigación en tiempos de COVID-19. En L. Torres-Barzabal y J.A. Morón-Marchena (coords.). Investigación e innovación en Educación Social. Estudios e investigaciones en tiempos de COVID-19 (pp. 41-54). Octaedro: Barcelona, España.

García-Tormo, J.V. (2018). Aplicación de tics (formularios on-line) como metodología docente activa en estudios de postgrado. International Journal of Developmental and Educational Psychology, 1, 199-208. https://doi.org/10.17060/ijodaep.2018.n1.v3.1257

Gikas, J. \& Grant, M. M. (2013). Mobile computing devices in higher education: Student perspectives on learning with cellphones, smartphones \& social media. Internet and Higher Education, 19, 18-26. https://doi.org/10.1016/j.iheduc.2013.06.002

González, M. A. \& González, M. A. (2016). El laboratorio en el bolsillo. Aprendiendo física con tu smartphone. Revista de ciencias, 6, 28-35. Available online: https://bit.ly/2UVA62Y (accessed on 5 February 2020).

Hamidi, H. \& Chavoshi, A. (2018). Analysis of the essential factors for the adoption of mobile learning in higher education: A case study of students of the University of Technology. Telematics and Informatics. 2018, 35(4), 10531070. https://doi.org/10.1016/i.tele.2017.09.016

Hedges, L. (1981). Distribution Theory for Glass's Estimator of Effect Size and Related Estimators. Journal of Educational Statistics, 6(2), 107-128. https://doi.org/10.3102/10769986006002107

Hinojo Lucena, F.J., Aznar Díaz, I. \& Romero Rodríguez, J.M. (2020). Mobile learning in the different educational stages. Bibliometric review of scientific production in Scopus (2007-2017). Revista Fuentes, 22(1), 37-52. https://doi.org/10.12795/revistafuentes.2020.v22.i1.04

Horwood, S. \& Anglim, J. (2021). Emotion Regulation Difficulties, Personality, and Problematic Smartphone Use. Cyberpsychology, Behavior, and Social Networking, 24(4), 275-281. https://doi.org/10.1089/cyber.2020.0328

$\mathrm{Hu}, \mathrm{X}$. \& Lai, C. (2019). Comparing factors that influence learning management systems use on computers and on mobile. Information and Learning Science, 120(7-8), 468-488. https://doi.org/10.1108/ILS-12-2018-0127

Kil, N; Kim, J; McDaniel, J.T.; Kim, J. \& Kensinger, K. (2021). Examining associations between smartphone use, smartphone addiction, and mental health outcomes: A cross-sectional study of college students. Health Promotion Perspectives, 11(1), 36-44. https://doi.org/10.34172/hpp.2021.06

Kukulska-Hulme, A; Sharples, M; Milrad, M; Arnedillo-Sánchez, I. \& Vavoula, G. (2009). Innovation in Mobile Learning: A European Perspective. International Journal of Mobile and Blended Learning, 1(1) 13-35. https://doi.org/10.4018/jmbl.2009010102

López-Noguero, F. (2008). La educación como respuesta a la diversidad. Una perspectiva comparada. Universidad Pablo de Olavide y Sociedad Iberoamericana de Educación Comparada: Sevilla, España.

López-Noguero, F. \& Pérez Serrano, G. (2012). La educación social del siglo XXI. Un esfuerzo de aclaración. In Cobos Sanchiz, D., Jaén Martínez, A., López-Meneses, E., Martín Padilla, A. H., Molina García, L., Eds. I Congreso Virtual Internacional sobre Innovación Pedagógica y Praxis Educativa INNOVAGOGÍA 2012 (pp. 1741- 1753). AFOE: Sevilla. Available online: https://bit.ly/3dZDlzh (accessed on 5 February 2020).

Gómez Camacho, A. \& Gómez del Castillo, M. T. (2015). Escritura ortográfica y mensajes de texto en estudiantes universitarios. Perfiles educativos, 37(150), 91-104.

Mancinas, A. (2018). Modalidades de cognición en un curso universitario basado en el aprendizaje móvil. Apertura: Revista de Innovación Educativa, 10(1), 40-55. Available online: https://bit.ly/39CvJiA (accessed on 4 February 2020). 
Mohammed, W.M. (2020). The obstacles that hinder the use of mobile learning applications among fourth grade university students in the college of education at the University of Baghdad. International Journal of Innovation, Creativity and Change, 11(7), 322-340. Available online: https://bit.ly/2yl9HOG (accessed on 3 March 2020).

Murphy, A; Farley, H; Lane, M; Hafeez-Baig, A. \& Carter, B. (2014). Mobile learning anytime, anywhere: what are our students doing? Australasian Journal of Information Systems, 18(3), 331-345. https://doi.org/10.3127/ajis.v18i3.1098

Nikou, S. A. \& Economides, A. A. (2021). A Framework for Mobile-Assisted Formative Assessment to Promote Students' Self-Determination. Future Internet, 13, 116. https://doi.org/10.3390/fi13050116

O'Malley, C; Vavoula, G; Glew, J; Sharples, M. \& Lefrere, P. (2003). MOBllearn: D4.1 guidelines for learning/teaching/tutoring in a mobile environment. https://bit.ly/3acS5Kg

Pablo de Olavide University (2019). Memoria Curso Académico 2018-2019. https://bit.ly/3FBKZgX

Paredes, W; Chávez, L. \& Vera, M. (2019). Communication and Technological Skills to Improve University Teaching Performance. In International Conference on Knowledge Society: Technology, Sustainability and Educational Innovation, TSIE 2019; Ibarra, Ecuador, 3-5 July 2019; Volume 1110 AISC, 385-392. https://doi.org/10.1007/978-3$030-37221-7 \quad 32$

Parsons, D. (2014). The Future of Mobile Learning and Implications for Education and Training. In M. Ally \& A. Tsinakos (eds.), Increasing Access Through Mobile Learning (pp. 217-229). Vancouver: Commonwealth of Learning \& Athabasca University.

Qi, C. (2019). A double-edged sword? Exploring the impact of students' academic usage of mobile devices on technostress and academic performance. Behaviour and Information Technology, 38(12), 1337-1354. https://doi.org/10.1080/0144929X.2019.1585476

Ramos, A. I; Herrera, J. A. \& Ramírez, M. S. (2010). Desarrollo de habilidades cognitivas con aprendizaje móvil: un estudio de casos. Comunicar, 17(34), 201-209. http://dx.doi.org/10.3916/C34-2010-03-20

Razzaq, A; Samiha, Y.T. \& Anshari, M. (2018). Smartphone habits and behaviors in supporting students self-efficacy. International Journal of Emerging Technologies in Learning, 13(2), 94-109. https://doi.org/10.3991/ijet.v13i02.7685

Reinoso, G.G.L; Barzola, K.M; Caguana, D.M; López, R.P. \& López, J.C.P. (2019). M- learning, un camino hacia aprendizaje ubicuo en la educación superior del Ecuador. RISTI - Revista Iberica de Sistemas e Tecnologias de Informacao, E18, 47-59. Available online: https://bit.ly/2V4ZRy1 (accessed on 3 February 2020).

Roig-Vila, R; López Padrón, A. y Urrea-Solano, M. (2021). Perfil del uso académico del smartphone entre estudiantes noveles universitarios españoles e iberoamericanos. American Journal of Distance Education, 35(1), 66-81. https://doi.org/10.1080/08923647.2021.1880730

Romero-Rodríguez, J. M; Aznar-Díaz, I; Hinojo-Lucena, F.J. \& Gómez-García, G. (2021). Uso de los dispositivos móviles en educación superior: relación con el rendimiento académico y la autorregulación del aprendizaje. Revista Complutense de Educación, 32(3), 327-335. http://dx.doi.org/10.5209/rced.70180

Rovira-Collado, J. (2016). Redes sociales en la universidad: profesionales, académicas y de lectura. Álabe: Revista de Investigación sobre Lectura y Escritura, 13, 1-18. http://dx.doi.org/10.15645/Alabe2016.13.4

Salcines-Talledo, I. \& González-Fernández, N. (2015). Diseño y Validación del Cuestionario "Smartphone y Universidad. Visión del Profesorado" (SUOL). Revista Complutense De Educación., 27(2), 603-632. https://doi.org/10.5209/rev RCED.2016.v27.n2.46912

Salcines-Talledo, I. \& González-Fernández, N. (2020). Educational applicatins in Higher Education. Study about the use in students and university professors. ENSAYOS. Revista De La Facultad De Educación De Albacete, 35(1), 15-30. https://doi.org/10.18239/ensayos.v35i1.1929

Salcines-Talledo, I; González-Fernández, N. \& Briones, E. (2020). The smartphone as a pedagogic tool. student profiles as related to its use and knowledge. Journal of New Approaches in Educational Research, 9(1), 91-109. https://doi.org/10.7821/naer.2020.1.454

Saroia, A. \& Gao, S. (2019). Investigating university students' intention to use mobile learning management systems in Sweden. Innovations in Education and Teaching International, 56(5), 569-580. https://doi.org/10.1080/14703297.2018.1557068

Sevillano, M.L. \& Vázquez, E. (2013). La universidad ante el reto del aprendizaje ubicuo con dispositivos móviles. Edetania: estudios y propuestas socio-educativas, 44, 33-46. Available online: https://bit.ly/3dZyUED (accessed on 4 February 2020).

Sharples M., Arnedillo-Sánchez I., Milrad M. \& Vavoula, G. (2009) Mobile Learning. In Balacheff N., Ludvigsen S., de Jong T., Lazonder A. \& Barnes S. (eds)., Technology-Enhanced Learning (pp. 233-249). Dordrecht: Springer. https://doi.org/10.1007/978-1-4020-9827-7 14

Shishakly, R. (2019). Smartphones enhance the management of learning processes in Higher Education: A case study in Ajman University, United Arab Emirates. In 10th International Conference on E-Education, E-Business, EManagement and E-Learning, IC4E 2019; Waseda University, Tokyo, Japan, 10-13 January 2019, 63-69. https://doi.org/10.1145/3306500.3306513

Torrado-Crespón, M. (2015). Uso del Smartphone y su reflejo en la escritura entre estudiantes de secundaria bilingües gallego - español. Digital Education Review, 28, 77-90 
Traxler, J. (2007). Defining, Discussing and Evaluating Mobile Learning: The moving finger writes and having writ... The International Review of Research in Open and Distributed Learning, 8(2), 1-12. https://doi.org/10.19173/irrodl.v8i2.346

Traxler, J. (2009). Learning in a Mobile Age. International Journal of Mobile and Blended Learning (IJMBL), 1(1), 1-12. https://doi.org/10.4018/imbl.2009010101

Traxler, J. (2011). Ethics in mobile learning - Moral movements? In I. Arnedillo Sánchez \& P. Isaías (Eds.). Proceedings of the IADIS International Conference Mobile Learning 2011 (pp. 95-101). Spain: IADIS Press.

UNESCO (2013). UNESCO policy guidelines for mobile learning. https://bit.ly/3iFuiLA

Veytia, M. G; Gómez, J. \& Morales, M. B. (2019). Research competences and technological mediation of Ibero-American doctoral students. IJERI: International Journal of Educational Research and Innovation, 12, 1-19. Available online: https://bit.ly/39NIC9O (accessed on 5 February 2020).

Zhao, X; Wan, X. \& Okamoto, T. (2010). Adaptive Content Delivery in Ubiquitous Learning Environment. In The 6th IEEE International Conference on Wireless, Mobile, and Ubiquitous Technologies in Education. National Central University, Kaohsiung, Taiwan, 11-15 April 2010; pp. 19-26. https://doi.org/10.1109/WMUTE.2010.10 